\title{
Entrepreneurship and the Face of Janus of Institutions: Stimulus Policies for High- Impact Entrepreneurs in Brazil and Russia
}

\section{Empreendedorismo e a Face de Janus das Instituições: Políticas de Estímulo ao Empreendedorismo de Alto Impacto no Brasil e na Rússia}

\author{
Gilberto Sarfati \\ Escola de Administração de Empresas de São Paulo - EAESP/FGV - Brasil \\ gilberto.sarfati@fgv.br \\ ORCID: 0000-0003-0772-5197
}

Submetido em 02/07/2018; Aprovado em 13/09/2018

\begin{abstract}
Institutional theory has been widely applied to the study of entrepreneurship. Based on the current understanding of the institutional gap, we suggest that the relationship between formal institutions and entrepreneurship in emerging economies is reminiscent of the Face of Janus. Janus is a mythological figure with two faces, one looking backward and the other looking forward. Therefore, he is associated with transition and the chaos connected with the ambiguous relationship between the past and the future. This ambiguity may be seen as characteristic of entrepreneurship in emerging economies. In other words, the Face of Janus that looks backward corresponds to the institutional void, and the face that looks forward corresponds to stimulus policies that promote high-impact entrepreneurs. In this article, we comparatively discuss two case studies in Brazil and Russia. In Brazil, the Agency for Innovation's (Financiadora de Estudos e Projetos - FINEP) INOVAR program while in Russia the Skolkovo Foundation. This article contributes to the entrepreneurship literature by advancing the concept of the institutional void in the context of emerging economies and by identifying strategies to develop high-impact entrepreneurship in two countries that have received little attention in previous articles.
\end{abstract}

Keywords: Public policies for entrepreneurship, high-impact entrepreneurs, entrepreneurship in emerging economies.

\section{Resumo}

A teoria institucional tem sido amplamente utilizada no estudo de empreendedorismo. A partir da compreensão atual do vazio institucional este artigo sugere que a relação entre as instituições formais e o empreendedorismo em economias emergentes tem a face de Janus. Na mitologia Janus é um deus de duas caras, uma olhando para trás e outra para frente. Por isso ele é associado com a transição e com o caos associado à ambígua relação entre o passado e o futuro. Esta ambiguidade pode ser vista como característica do empreendedorismo em economias emergentes. Em outras palavras, a face de Janus que olha para trás é a do vazio institucional e, a que olha para frente, a de políticas de estimulo que promovem os empreendedores de alto impacto. 0 artigo explora de forma comparada dois estudos de caso no Brasil e na Rússia. No Brasil, foi explorado o programa FINEP (INOVAR) e sua relação com o empreendedor Daniel Heise do Grupo Direct e na Rússia, a relação entre a Fundação Skolkovo e o empreendedor Yuri Deigin da Pharma Bio. 0 artigo contribui com a literatura de empreendedorismo aperfeiçoando o conceito de vazio institucional no contexto das economias emergentes; identificando na prática as estratégias de desenvolvimento do empreendedorismo de alto impacto em dois países pouco cobertos em artigos anteriores e explorando diretamente a relação das instituições com o indivíduo empreendedor de alto impacto nestas economias emergente aprofundando a compreensão da relação macro-micro.

Palavras chaves: Políticas públicas de empreendedorismo, empreendedores de alto impacto, empreendedorismo em economias emergentes. 


\section{Introduction}

Institutional theory has been widely applied to the study of entrepreneurship (Ajjan et al, 2015; Shane \& Foo, 1999; Peng, 2006); more specifically, the concept of the institutional void (Khanna \& Palepu, 1997) is frequently cited as an inhibitor of entrepreneurial activity in developing countries (Armanios et al, 2017; Luthans \& Ibrayeva, 2006; Peng, 2000). However, the institutional void may be filled by informal institutions as reflected in cultures, traditions, conventional relationships, and norms (Korppoo, 2018; Puffer, McCarthy, \& Boisot, 2009; Bjerregaard \& Lauring, 2012). The recent entrepreneurship literature has emphasized the negative effects of the institutional void and the filling of this void by informal institutions. There are relatively few studies that explore the other side of the formal institutions in emerging countries, namely, these countries' stimulus policies.

Based on the current understanding of the institutional void, this article suggests that the relationship between formal institutions and entrepreneurial activities in emerging economies is reminiscent of the face of Janus. Janus is a mythological figure with two faces, one looking backward and the other looking forward. He is, therefore, associated with transition and the chaos connected with the ambiguous relationship between the past and the future. The face of Janus may be associated with the transitions facing large emerging economies, such as those of the BRIC countries (Brazil, Russia, India, and China).

Entrepreneurs in these economies face enormous regulatory obstacles, which favor the informal economy (Kistruck et al, 2015; Webb, Tihanyi, Ireland, \& Sirmon, 2009) and ventures that take advantage of institutional voids (Tracey \& Nelson, 2011). At the same time, the governments of some of these countries have designed specific programs to support the development of high-impact entrepreneurs. In other words, the face of Janus that looks back corresponds to the institutional void, and the one that looks ahead corresponds to stimulus policies that promote the development of an entrepreneurial culture and, more specifically, high-impact entrepreneurs.

In this article, we comparatively examine case studies of two high-impact entrepreneurs supported by public policies in Brazil and Russia. Executives who are connected to the FINEP program and an executive of the venture capital firm DGF INVESTIMENTOS were interviewed as well as a successful entrepreneur who invested in DGF INVESTIMENTOS, Daniel Heise, the founder of Grupo Direct. In Russia, the case of the Skolkovo Foundation and of the entrepreneur Yuri Deigin of Pharma Bio was examined.

This article makes three contributions. The first is improving the concept of the institutional void in the context of emerging economies, demonstrating that inappropriate regulatory environments prevent governments from actively promoting high-impact entrepreneurship. Second, in this article, institutional theory is connected to the study of entrepreneurship in emerging economies, identifying, in practice, the development strategies for high-impact entrepreneurship employed in two countries that have received little attention in previous articles, namely, Brazil and Russia. Third, the relationship of institutions with individual high-impact entrepreneurs in these emerging economies is directly explored, deepening the understanding of the macro-micro relationship.

This article is complementary to the work of Kshetri and Dholakia (2011), who note that there are few studies that make comparisons among countries in terms of the effects of institutions on entrepreneurship (especially among emerging countries). In addition, this study deepens the understanding of entrepreneurial activity in emerging countries (Karagad, 2018; Bruton, Ahlstrom, \& Obloj, 2008).

The discussion is structured in three sections. First, we present a literature review on the relationships among institutional theory, the institutional void, and entrepreneurship, followed by the relationship between high-impact entrepreneurship and economic development, which is important in justifying the political actions of governments. Next, we discuss the methodology through the presentation of the structure of the case studies in Brazil and Russia. Third, we present the analysis of the case studies along with the conclusions and a discussion of practical implications, the limitations of the study, and suggestions for future research.

\section{Theoretical framework}

Although it is not possible to categorically claim that entrepreneurship causes economic growth, new evidence (Bjørnskov \& Foss, 2016; Acs, 2008) indicates that some companies with accelerated growth, known as gazelles, high-growth, or high-impact companies, have a significant impact on the 
generation of employment and economic growth.

Birch, Haggerty, and Pasons (1995) define gazelles as companies that began with a foundation of US $\$ 100,000$ and have had annual sales growth of at least $20 \%$. The Organization of Economic Cooperation and Development (OECD) (2011) defines high-growth companies as companies that generate an increase in the number of employees of more than $20 \%$ per year over three years, considering a minimum of ten employees at the beginning of the observed period. Gazelles are a subtype of high-growth companies that are less than five years old and have exhibited growth over a three-year period in the number of employees or in revenue of at least $20 \%$ per year.

Henrekson and Johansson (2010), in a survey of 20 articles on the topic of gazelles and the generation of employment, conclude that a small number of companies generate a disproportional increase in new jobs. The study indicates that this relationship is especially pronounced when gazelles continue to grow during recessions.

Coad, Cowling and Siepe (2017) identify that most high-growth firms starts with employment growth followed by sales growth and then operating profits growth and finally growth on assets.

Other research (Abubakar \& Mitra, 2017; Moreno \& Casillas, 2007; St-Jean, Julien, \& Audet, 2008) indicates that the accelerated growth of these types of companies is generated by the training, experience, knowledge spillover and capacity of the entrepreneurial venture's management, the company's strategic decisions, proximity to clients, and access to resources, such as capital to finance growth, human capital, and technology. High-impact entrepreneurs tend to be creative, better tolerate market uncertainties, exercise great leadership, have the ability to form relationship networks, and compete aggressively (Cunneen \& Meredith, 2007). There is further evidence that when institutions promote entrepreneurship, economic growth follows (Pereira \& Temouri, 2018; Johnson, Kaufmann, \& Zoido-Lobaton, 1998; McMillan \& Woodruff, 2002).

According to Scott (2001), institutional theories have been widely explored in fields such as sociology, economics, and political science. For Scott, institutions are social constructs that attain a high degree of resilience. They are composed of the regulatory, normative, and cognitive pillars that provide stability and meaning to social life. Scott's definition carries a contemporary sociological perspective that privileges the social construction process of the institutions.

The regulatory pillar is related to the formal structures codified in rules that have clear mechanisms for the application of the law. The normative institutions that manifest themselves through social norms and conventions are less formal, whereas cognitive institutions are related to axiomatic beliefs related to the expected behaviors in a particular culture (Manolova, Eunni, \& Gyoshev, 2008).

The perspective of North (1990) has been most frequently associated with the impact of formal and informal institutions on entrepreneurship (Karppoo, 2018; McCarthy, \& Puffer, 2016 Ahlstrom \& Bruton, 2010; Martí \& Ventresca, 2012). North interprets formal institutions as the rules applied to political, legal, and economic systems, whereas informal institutions are codes of conduct that manifest themselves through predictable social and cultural aspects of daily life.

A condensed overview of the perspectives of Scott and North presents a view that is based on institutions and is applied to the strategy studies widely applied and spread by Peng and colleagues (Zoogah, Peng \& Woldu, 2015; Lee, Yamakawa, Peng, \& Barney, 2011; Peng, 2000, 2006; Peng, Sun, Pinkham, \& Chen, 2009).

In developing economies, formal institutional structures are frequently absent or deficient. In these situations, an institutional void emerges that increases transaction costs and limits economic growth (Smit, Pennings \& Bekkum, 2017; Khanna \& Palepu, 1997). Studies on the institutional void and entrepreneurship have focused on two concepts: the negative effect of the institutional void on entrepreneurial activity and how informal institutions tend to fill the institutional void.

Baumol (1990) was a pioneer in examining the impact of institutions on entrepreneurial activity and assumes that entrepreneurial talent is relatively constant and that institutions therefore direct their allocations among productive, unproductive, and destructive activities. Sobel (2008) and Sobel and Clark (2016) empirically tested Baumol's hypothesis and concluded that institutional quality is highly related to entrepreneurial productivity.

Ahlstrom and Bruton (2010) empirically note that, in economies in transition, rapid regulatory changes discourage the registry of companies with the government, thereby limiting long-term growth opportunities. Gohman (2012), upon studying the institutional environments of 18 countries, concluded that regulatory institutions directly affect the number of latent entrepreneurs. 
Webb, Tihanyi, Ireland, and Sirmon (2009) propose that (formal) institutional incongruence and the weak performance of institutions increase the recognition of the opportunities available in the informal economy.

The conclusion that excess regulation, bureaucracy, imperfect intellectual property rules, and bankruptcy, among other aspects of informal institutions, directly and negatively affect entrepreneurial activity is widely accepted in the literature (De Jong, \& Van Witteloostuijn, 2015; Aidis, 2005; Luthans \& Ibrayeva, 2006; Peci, Kutlovci, Tmava, \& Shala, 2012; Manolova; Eunni \& Gyoshev, 2008; Smallbone \& Weder, 2001).

One of the ways it is possible to outline the institutional void through informal institutions is bricolage, a concept originally developed by Lévi-Strauss (1966) that refers to situations in which people "make do with the resources that they have at hand." This concept has already been applied in the entrepreneurship literature by Baker and Nelson (2005), who demonstrate how 29 companies socially construct their resource environment by frequently testing the limits of rules and norms. Mair and Martí (2009) demonstrate that the non-governmental organization (NGO) BRAC was capable of building innovative institutional arrangements in Bangladesh by combining and reallocating the resources that it had at hand to promote the reduction of poverty among the country's women. In analyzing the same NGO, Mair, Martí, and Ventresca (2012) conclude that the institutional void is not really a void because it is filled by a complex institutional context that includes the interaction between market institutions (formal) and local institutions (informal rules and norms established by the local social groups). A recent special issue of Entrepreneurship \& Regional Development widely covered this debate. Tasavori, Kwong and Pruthi (2018), for example, discuss how social enterprise explores internal and external resources to succeed while Kickul et al (2018) notes that bricolage may hamper entrepreneur's ability to look to other relevant resources.

This agency-structure relationship is broadly related to the concept of institutional entrepreneurship; that is, new institutions emerge when actors see an opportunity to actualize their interests (DiMaggio, 1988). In this regard, Tracey and Nelson (2011) suggest that in emerging economies, some entrepreneurs create business opportunities from the institutional voids, operating as institutional brokers, which reduces the risks for other actors; propagating the institutional voids by offering solutions that constitute new institutional arrangements as an alternative to existing arrangements; and building institutional bridges, through which the entrepreneur creates new businesses by introducing business concepts that have worked in other markets and adapting them to the local institutional context.

Puffer, McCarthy, and Boisot (2010) explore the filling of the institutional void in emerging economies by informal institutions in terms of cognitive-cultural aspects. More specifically, the authors demonstrate that blat in Russia and guanxi in China function as mechanisms to establish trust in relationship networks in the face of the weakness of formal institutions.

There is a consensus in the literature that the government molds institutional structures, encouraging certain activities and discouraging others (Minniti, 2008). Similarly, governments tend to structure policies that may encourage the development of entrepreneurship to promote the development of an entrepreneurial culture (Figueroa-Armijos \& Johnson, 2016; Audretsch, Keilbach, \& Lehmann, 2006; Keilbach, Tamvada, \& Audretsch, 2009).

As noted above, the literature thus far has overemphasized the regulatory aspects of institutions and informal mechanisms for filling the institutional void. The influence of public policies in stimulating entrepreneurship is infrequently addressed in relation to the concept of the institutional void. In this article, we argue that in emerging economies, stimulus policies for entrepreneurship comprise the nonregulatory side of the formal institutions that coexist with the institutional void, representing the face of Janus in the relationship between institutions and entrepreneurship.

In other words, the regulatory pillar of Scott (2011) is underdeveloped in emerging economies; however, through stimulus policies, governments are capable of developing the cognitive pillar, which is related to the development of an entrepreneurial culture through the promotion of the venture capital industry, the development of entrepreneurial education, and a higher incidence of high-impact entrepreneurs. Kshetri (2007) demonstrates that in the case of China, institutional changes have occurred not only in the regulatory pillar but also in the normative and cognitive ones as the social acceptance of entrepreneurs has rapidly increased, particularly in relation to high-technology entrepreneurship. 
Stimulus policies do not fill the institutional void in the regulatory sense, at least not in the short term. However, they reveal the willingness of the state to fill the institutional void in the normative and cognitive senses. In other words, through a stimulus policy, the government is not the only actor for institutional change but is the central actor that allows other actors, such as educational institutions, financial markets, and entrepreneurs, to deepen their connections and relationships.

\section{Methodology}

In this study, we adopt a qualitative, exploratory methodology by conducting a comparative case study. Stimulus policies for entrepreneurship in developing countries are relatively new, not welldocumented, and lacking data. The nature of the problem, the face of Janus of the institutions in emerging economies, is conducive to an exploration via case studies (Eisenhardt, 1989; Yin, 2003).

The choice to perform a comparative case study reflects the understanding of the characteristics common to emerging economies, or rather, the observation of the institutional voids that coexist with high-impact entrepreneurs who are incentivized by public policies. Case studies are optimal instruments for understanding complex causal relationships in real-world situations because they allow for a description of the context in which episodes and interventions take place as well as the exploration of the situation when there are no clear results (Yin, 2003).

First, we selected two emerging countries with large economies, Russia and Brazil (the sixth and seventh largest economies in the world in terms of Gross Domestic Product - GDP), with totally different economic and cultural histories. Entrepreneurial activity, particularly pertaining to the role of government, has received little attention in the international literature in both cases.

Russia and Brazil are in the same phase of economic development, the efficiency-driven phase. The former is ranked 47 while the latter in 57 out of 64 countries in the global ranking of entrepreneurship driven by opportunity/necessity (GERA, 2017).

The public policies to stimulate entrepreneurship selected for analysis are the Skolkovo Foundation in Russia and FINEP (INOVAR) in Brazil. Both are innovative programs within their respective economies. The former is part of an attempt by the Russian government to create an ecosystem of high-impact entrepreneurship in the city of Skolkovo, near Moscow. The latter is a program that seeks to foster the creation of a risk capital industry in Brazil. Both cases were selected for being drivers of stimulus programs for high-impact entrepreneurship.

We used in-depth semi-structured interviews and documentary research to construct the case study. To build the cases, we interviewed actors involved in the entire chains of the programs. In other words, we chose to reconstruct the history of the connection between high-impact entrepreneurs and the government agents who choose to favor entrepreneurs. In the case of Brazil, the government relationship was indirect, through venture capital; whereas in Russia, this relationship was direct.

The reconstruction of the relationship between the agents is important for the understanding of how entrepreneurs deal with the institutional void in practice; why the government decides to support them; and what, in their view, justifies stimulus policies for high-impact entrepreneurship.

All interviews were based on semi-structured questionnaires and lasted approximately one hour. In Brazil, the interviews were conducted between April and July 2012 in the cities of São Paulo and Rio de Janeiro. All interviewees authorized to publish their names. Daniel Heise, a high-impact entrepreneur of Grupo Direct, was interviewed along with Patrick Arippol, a manager in the venture capital firm DGF INVESTIMENTOS, and Patricia Freitas, Eduardo Lopes, and Maurício Marques, who are managers at FINEP (INOVAR). The interviews in Russia were conducted in October 2012 in Moscow. Yuri Deigin, the high-impact entrepreneur of Pharma Bio, was interviewed, along with Alexander Lupachev, Eduard Kanalosh, and Seda Pumpyanskaya of the Skolkovo Foundation.

The high-impact entrepreneurs were selected based on the criterion of being an example of the program's success. In the case of FINEP (INOVAR), there are few cases that have seen the exit of venture capital funds. Within this pool of companies, we entered into direct contact with the interviewed entrepreneur, who later became the bridge to DGF INVESTIMENTOS, one of the main vehicles benefitting from INOVAR. In the case of Russia, we established direct contact with the Skolkovo Foundation, which pre-selected five entrepreneurs. The story of Yuri Deigin was selected as best representing the positive effect of the Skolkovo Foundation in its short life.

The questions for FINEP (INOVAR) and the Skolkovo Foundation focused on the government's motivation in supporting the program, the selection process, and the relationship with the funded entity. 
In the specific case of Brazil, upon interviewing the manager of DGF INVESTIMENTOS, the dimensions of the relationship with FINEP were addressed as well as the selection process and the relationship with the entrepreneur. In the case of the high-impact entrepreneurs, their personal histories were discussed, focusing on the motivation to engage in entrepreneurship, the history of the company, the role of the institutional void in the decision to undertake an entrepreneurial venture, and the relationship with FINEP and the Skolkovo Foundation.

We conducted the interviews in Portuguese and English. All interviews were recorded with the application Audionote, allowing for the generation of annotations that were synchronized with the recorded voices. The interviews were transcribed through the Dictapad application and were subsequently coded and analyzed.. Finally, to close the loop from 2012 up to 2018 we researched the trajectory of both entrepreneurs and their companies.

Documental data were found mainly through secondary sources such as news, reports and other sources that provided information about the institutions, companies and people evaluated in this article.

The procedure of constructing the cases follows the recommendations of Einsenhardt (1989) in the definition of the research question, selection of the relevant cases, data collection, field research, data analysis, construction of the hypotheses through the observation of patterns, comparison with conflicts in the literature, and theoretical conclusions. Through the comparative case study, we performed a triangulation of the data to identify patterns in different contexts. In other words, the rigorous comparison of the documental analysis to the interviews should demonstrate the robustness of the cases and should allow for the construction of relevant and valid theory (Stake, 1995; Van Maanen, 1988).

\section{Presentation of the cases}

\section{- Skolkovo Foundation}

Skolkovo was funded by the Russian government with the objective of fostering a new cycle of technological innovation in the country. After the end of the Cold War, the country lost competitiveness when thousands of highly trained researchers emigrated to the West. The government, armed with capital derived primarily from the oil and gas industry, founded Skolkovo with capital estimated at US\$ 6 billion.

The purpose of Skolkovo is to create an ecosystem of innovation similar to that found in the Silicon Valley. Skolkovo is a city located 20 kilometers from Moscow, and a technology city is being built there. The new buildings there will house residences and companies organized around IT, energy efficiency, nuclear technology, biotechnology, and aerospace technology clusters. Not only startups will operate in Skolkovo; large companies, such as Cisco, Microsoft, Intel, and GE, will also set up research and development (R\&D) centers there. Other key components of the system include Skolkovo Tech, an institution of higher education developed with the Massachusetts Institute of Technology (MIT) and the Skolkovo Foundation.

The Skolkovo Foundation began to operate in 2010. Between that year and 2012almost 3,500 companies have applied to the foundation, 670 have received resident status (fiscal incentives), and 140 have received subsidies totaling US\$ 270 million. The Skolkovo Foundation offered grants that reached $100 \%$ of the company's capital in the initial state (seed), with a co-investment of $25 \%$ of the capital in companies in the expansion stage (up to US\$ 10 million). In 2017 Skolkovo formed a complex ecosystem with 30,000 people leaving in the city, 1809 participating companies, 2072 grants approved, 150 companies funded also by private investors.

The Skolkovo Foundation promotes startups through the following mechanisms: a) generous tax exemptions for companies installed at the pole, b) simplification of bureaucracy, c) access to local and international venture capital funds, d) exposure in the local and global media, e) and non-dilutable financial subsidies (not all selected companies receive the subsidies, and those that do increase their capital without diluting the partners' capital).

\section{- Yuri Deigin (Pharma Bio)}

Pharma Bio was founded by Prof. Vladislav Deigin and Yuri Deigin, who are father and son. The former is a renowned biotechnology researcher who emigrated to Canada in the 1990s in search of 
investments to bring his scientific research to the market. In Canada, he became involved in several ventures for which only part of the clinical tests were conducted in Russia.

Yuri Deigin studied Computer Science at the University of Toronto. He worked at IBM, but in 2002 and 2003, he launched a startup with friends in the area of location-based services. The idea was to create a blind-dating location service. The company was ahead of its time in some ways because cellular phones with GPS arrived on the market much later. The company also developed a mobile payment system. In a period of three years, Yuri Deigin undertook these entrepreneurial activities while continuing to work at IBM.

In 2008, he entered Columbia University's Master in Business Administration (MBA) program to develop his business skills. During the course of the MBA program, he actively presented a business plan for a new biotechnology company to potential investors in New York. In 2010, however, the opportunity emerged to present the project to the Skolkovo Foundation, which had just been created. At the end of 2010 , the project was approved with the concession of a subsidy of US\$22.3 million (under the current policy, the limit is US\$ 10 million), which led Yuri, who had left the country as a teenager, to return and manage the new venture, Pharma Bio, in Russia. The Shemyakin \& Ovchinnikov Institute of Bio-Organic Chemistry, where Prof. Vladislav Deigin has always conducted his research, is also a cofounder of and an investor in the company.

At the time that they joined Skolkovo, Pharma Bio had approximately 50 employees, seven of whom were doctors. Its portfolio includes five peptide drugs and more than 90 registered patents. Some important benchmarks included the beginning of pre-clinical tests of the C12 compound to combat Alzheimer's disease, in 2011, and the 2012 launch of Thymodepressin, an immune suppressor for the treatment of autoimmune disorders, on the Russian market.

Yuri Degin acted as Chief Operational Officer (COO) between January 2011 and May 2017. In 2017 the entrepreneur launched a new startup, Youthereum Genetics. Pharma Bio is based on Skolkovo and commercialize Thymodepressin and have other 4 drugs in different phases of clinical trials.

\section{- FINEP (INOVAR)}

FINEP is a public company linked to the Brazilian Ministry of Science, Technology, and Innovation whose objective is to foster science, technology, and innovation in companies, universities, technological institutes, and other public and private entities. In 1999, FINEP mapped the mechanisms for financing innovative companies in Brazil, reaching the conclusion that there were very few private equity and venture capital companies in the country and that this financing modality was virtually unknown by small and medium companies. In addition, pension funds, which managed more than US\$ 70 million, did not have an appetite for the sector.

In October of 2001, along with the Inter-American Development Bank (IADB), FINEP founded INOVAR with the objective of fostering the development of a risk capital industry in the country. Through the Multilateral Investment Fund (MIF), the IADB contributed US $\$ 1.12$ million out of a budget of US\$ 3.7 million for a period of five years. In other words, INOVAR began with very little money to achieve its objectives.

INOVAR at first fostered the creation of the Brazilian Association of Private Equity and Venture Capital (Associação Brasileira de Private Equity e Venture Capital - ABVCAP). Another initially created mechanism was the INOVAR Venture Forum, which provides training for entrepreneurs and connects them with potential investors through events at which entrepreneurs can present their businesses and interact with one another and potential investors. Through INOVAR I, which lasted from 2001 to 2006, several private equity and venture capital firms, such as Status, DGF INVESTIMENTOS, and Fir Capital, managed to raise funds. During this period, Lupatech, an industrial valve company strongly geared toward the oil industry, participated in one of the first Venture Forums, and later, several rounds of investments were launched on the stock market in 2006. By attracting pension funds, there was a noticeable development of the industry in this period, especially for private equity.

In INOVAR II, which lasted from 2007 to 2012, the objective shifted toward the development of the next links in the chain, or rather, attracting venture capital firms and developing financing mechanisms for companies in their early stages (i.e., seed money). More recently, INOVAR started supporting the formation of networks of angel investors. Until a little less than five years ago, there were practically no angels in Brazil.

In the period from 2001 to 2011, INOVAR attracted 17 partners, including 11 pension funds, and 
contributed to the raising of more than US\$ 2 billion by approximately 24 funds. Operational costs during this period were considerably low, at around US\$13 million. The last call for INOVAR was in August of 2014. In 2017, FINEP moved to a strategy of direct funding of startups in the seed stage with the program FINEP Startup.

\section{- DGF INVESTIMENTOS}

DGF INVESTIMENTOS was founded in 2001 by Sidney Chamech with the objective of managing a private equity fund. Through DGF INVESTIMENTOS Capital I, several investments were made between 2002 and 2004, even in Grupo Direct. Through the close FINEP-INOVAR relationship, the institution has gradually increased its commitment to initial stage and startup investments over the course of the last decade, forming funds that have attracted several institutional partners, including the Brazilian Support Service for Small Companies (Serviço Brasileiro de Apoio às Pequenas Empresas - SEBRAE), the IADB, and the holding company for the National Bank for Economic and Social Development (Banco Nacional de Desenvolvimento Economico e Social Participações - PBNDESPar).

\section{- Daniel Heise (Grupo Direct)}

Daniel Heise has always exhibited an entrepreneurial spirit, even when the Brazilian economy was considered to be unstable. In 1994, for example, while studying management at university and interning at Arthur Andersen, he founded Restaurante Cozumel with friends in São Paulo, which was enormously successful. Despite its success, he sold his share in three months with a return of $300 \%$ on the invested capital. Between 1994 and 1998, he worked at Banco Matrix on securities operations in international markets. In 1999, Daniel Heise, with a childhood friend, created the Internest incubator, which generated 12 projects. One of the successful projects was Ingresso Fácil (Easy Ticket), in partnership with BWA, a site that began selling tickets for soccer games and currently sells tickets for theatrical productions, movies, and concerts, among other events.

In 2000, Daniel and his team set up an online chat service for Ingresso Fácil. This chat service appeared to be an enormous business opportunity, and they therefore spun it off, creating Customer First, which soon attracted Banco Itaú as a client. In the same year, Daniel sold his share in Ingresso Fácil, dismantled the incubator, and focused his energy on this new project. He also negotiated a merger with the startup Direct Talk during the same year and at the same time secured funding from Rio Bravo Investimentos. Participation in the Third Venture Capital Forum of FINEP in April 2001 greatly facilitated the reception of the first rounds of investment. DGF INVESTIMENTOS began plans to expand Daniel's businesses in 2004, with the creation of Grupo Direct, which today consists of Direct Talk, DTM, Direct B2, and Scup. In 2011, DGF INVESTIMENTOS exited from Grupo Direct by selling its shares to Fundo 1188. In 2012, the group had 150 employees and d revenues of approximately US\$14.5 million. After 2012, Daniel became investor in DGF funds. In 2015, Scup was sold to Spriklr and Daniel moved to Miami to become CEO of the company there. In 2018, he became interim CFO of W12 a company specialized in software solutions for gyms.

\section{Results}

FINEP (INOVAR) in Brazil and the Skolkovo Foundation in Russia were the main programs that promoted early-stage high-impact entrepreneurship in these two countries. In both cases, the presence of a well-formed bureaucracy is noteworthy; this bureaucracy brings previous market experience to the promotion of public policies. The market view also facilitates the recognition of the institutional voids that negatively impact entrepreneurial activity. This recognition was transformed into practical actions to promote high-impact entrepreneurship.

The manager of FINEP (INOVAR) since the beginning of the program, was Patricia Freitas, she has a master's degree in Environmental Technology from Imperial College London and an MBA from COPPEAD Graduate School of Business at the Federal University of Rio de Janeiro. She was previously at Terra Capital, an investment fund focused on biodiversity, and managed the program from its inception until 2012. The role of FINEP in filling in the institutional void is noted by Patricia, who asserts that "INOVAR was developed by FINEP based on the diagnosis that the country has high scientific production yet low social appropriation of this knowledge. FINEP identified venture capital as a very appropriate financial instrument to close this type of gap."

This perception of the role of the institution is also shared by Seda Pumpyanskaya, the Vice- 
President of International Relationships and Communications of the Skolkovo Foundation: "in the decades from 1950 to 1970, Russia (the Soviet Union) believed itself to be among the leaders in the race for technological innovations. Between the decades of 1980 and 1990, the country 'missed the train' of technological development. After 20 years of liberal development in Russia, there is a perception in the government that the future lies with technological development...There is a perception that Russia has always had an advantage in talented people, yet many of them have left the country in search of better work conditions. Skolkovo is an instrument that fills this gap, making it possible to bring technological development back to Russia."

Seda and other interviewees at the Skolkovo Foundation are repatriated individuals who were motivated to return to Russia by the challenge and quality of the project. Seda lived outside of the country for 15 years working on several missions of the Organizations of the United Nations and at the European Council. Alexander Lupachev, the Chief Investment Officer at the Skolkovo Foundation, has an MBA from Harvard and was a vice-president at Delta Private Equity and a manager at Finam Capital. Ed Kanalosh, director of investments at the Skolkovo Foundation, also has an MBA from Harvard, a doctorate in medicine from the National Medical University of Kiev, and a career that includes working as a consultant with McKinsey \& Co., serving as a director at several private equity firms and as a vicepresident at Trust Investment Bank.

\section{- Selection processes}

The Skolkovo Foundation believes that subsidies are the most appropriate instruments to promote early-stage entrepreneurship. This is partially motivated by supplying a potential pipeline of high-impact companies in later stages to two other institutions linked to the Russian government. Russian Venture Capital (RVC) is a fund of funds with a late-stage focus, and Rusnano specializes in large industrial projects with technology transfer involving investments greater than US\$ 50 million. The Skolkovo Foundation requires co-investments as a pre-condition for subsidies. The candidate companies go through a selection process in which a panel of independent specialists, which is not only composed of Russians, evaluates projects both for the provision of resident status to companies in Skolkovo and the provision of subsidies. In the specific case of Yuri Deigin and PharmaBio, the project was selected as a function of the innovative character of the research, the commercial potential of the venture, and the quality of the entrepreneurial team.

In the case of FINEP (INOVAR), the decision to promote high-impact entrepreneurship relates two large mechanisms: the promotion of forums, which are meetings between high-impact entrepreneurs and potential investors, and the fund of funds mechanism. The preference for these mechanisms is in seeking to generate a multiplier effect. Through the forums, public and private institutions come together to promote events with the idea that a unique dynamic is created in each region that will forgo FINEP in the future promotion of relationships between high-impact entrepreneurs and investors. Selection for the forums is based on the criteria of innovation in entrepreneurship, market potential, team quality, and high potential for financial return.

With regard to DGF INVESTIMENTOS, the venture capital vehicle was selected through a public call in which managers presented proposals on the focus and management of investments to a bank comprised of specialists from FINEP and institutional investors (such as pension funds). The selection criteria are the team, governance mechanisms, the actions of the manager in relation to the companies receiving investment, the profile of the companies in which the manager intends to invest, and the exit strategy for the companies receiving investments. Once the selection was performed, FINEP became part of the investment committee, thus participating in the selection of high-impact entrepreneurs.

In turn, DGF INVESTIMENTOS selected the entrepreneurs as a function of high return potential (scalability) and the quality of the team (the humility, motivation, and experience of the entrepreneurs). In the specific case of the selection of Direct Talk and Daniel Heise, DGF INVESTIMENTOS considered the profile of the entrepreneurial team, the company's market potential, and the company's business model (in that order). DGF INVESTIMENTOS recognizes that FINEP has played a critical role in fostering the establishment of a venture capital industry in Brazil, particularly in fostering early-stage entrepreneurship.

\section{- Promotion of high-impact entrepreneurship}

The issue of the role of the Russian government in the repatriation and retention of talent appears 
to be a central element to Skolkovo. The story of Yuri Deigin and his father is quite representative of the current movement of fostering high-impact entrepreneurship in the country. As noted above, with the collapse of the Soviet Union, Russia experienced almost two decades of an exodus of talent. Skolkovo (together with RVC and Rusnano) functions as a mechanism to attract this talent back to the country and to retain researchers to work in the new high-potential companies or to launch new ventures.

Yuri and his father lived in Canada and were certainly going to engage in entrepreneurship outside of Russia; however, the biotechnological cluster in Skolkovo became an interesting setting, and the entrepreneurs were attracted by Skolkovo's potential offerings (subsidies, attractive tax structure, network of support relationships for new investment rounds). On the decision to return to Russia, Yuri asserts that, "after the approval of the project by Skolkovo at the end of 2010 with the guarantee of financing in 2011, I saw myself in the dilemma of returning to Toronto, where I had lived for most of my life, or returning to Russia. In the spirit of capturing the opportunity when it emerges, it seems that I realized that this was a unique chance that I could not let pass by."

In less than two years, the company experienced rapid growth in terms of the number of employees, drugs, and studies in its portfolio. None of this would be taking place in Russia if it had not been for the attractive conditions provided by Skolkovo. The Skolkovo Foundation continues to support the company, and, at the time of the interview, it was mediating the negotiation of a potential investor for the company.

In the case of Daniel Heise and Direct Talk, FINEP (INOVAR) was involved at two moments in the company's history. The first was when the company participated in one of the first Venture Capital Forums in 2011; Rio Bravo Investimentos was introduced to the company at the event and made the first contribution. Later, in 2004, DGF INVESTIMENTOS began plans to expand the company and exited in 2011.

After the exit, Daniel Heise (as an individual) became a shareholder in the DGF INOVA fund; that is, he went from receiving investments to being an investor. He joined with other entrepreneurs who had withdrawn from DGF and built one of the first cases in Brazil in which the entrepreneurs who had benefited from the venture capital industry ended up becoming shareholders of the funds.

According to Daniel Heise, "the participation of FINEP was critical for my participation in the fund, otherwise I would not have invested... We have had a great relationship with FINEP since the beginning. It was our participation in the Venture Capital Forum that brought visibility from investors. In 2007, we captured resources in another FINEP program, that of an economic grant. FINEP has always been present in the history of the company."

Through the story of Daniel Heise and Direct Talk, it is possible to see that FINEP was present at several moments of the company's history, making it an important driving force at critical moments in the company's growth. The role of the institution is widely recognized by the entrepreneur, so much so that he continues to be involved in the cycle, only now as a shareholder-investor. In other words, along with FINEP and the managers of DGF INVESTIMENTOS, Heise provides his opinion on potential investments and coaches companies that are receiving investments.

\section{- Entrepreneurship and institutional barriers}

Skolkovo offerd a total tax exemption of up to US\$ 1 million in revenues and a reduction in taxes in the subsequent revenue ranges; in addition, the system of collection and accountability is less complex than the conventional Russian system. These conditions were important in the decision of Yuri Deigin to engage in entrepreneurship in Russia. According to Deigin, "the company would exist anyway but probably not in its current form." In other words, many entrepreneurs seek resident status in Skolkovo, independent of the possibility of receiving subsidies, to have access to a less complex and less onerous tax system.

In the case of Brazil, Heise encountered the same institutional barriers for engaging in entrepreneurial activities as any other entrepreneur. Especially at the end of the 1990s and the beginning of the 2000s, this environment was significantly more macroeconomically unstable than in the current decade. Although he may have resented the institutional environment of the time, Heise says that it "never prevented me from engaging in entrepreneurship. The feeling of doing something that is important and transformative made me see these barriers as very small. Even in the worst periods of economic crisis, I never thought about giving up...the dream of building something large always motivated me." 
Even though the FINEP program does not manage tax issues for entrepreneurial ventures, the program is based on the premise that venture capitalists invest in entrepreneurs that may bring in high rates of return; in other words, they are entrepreneurs who, by definition, are capable of overcoming barriers such as a complex and onerous tax system and an economy with one of the highest interest rates in the world.

\section{Conclusion}

In this study, we identified two entrepreneurship stimulus programs in emerging economies that promoted high-impact entrepreneurship despite the continuing and accentuated existence of the institutional void in Brazil and Russia.

In other words, through the construction of relationships between institutions and entrepreneurs, it was possible to identify the face of Janus of the institutions in these countries. On one hand, the institutional void reflects regulatory barriers and a poor position on the Ease of Doing Business ranking of the World Bank; on the other hand, this void leads to institutions designed by the government to fill in gaps in the promotion of an innovative entrepreneurial culture.

Despite significant differences in the design of the structure of the FINEP (INOVAR) and Skolkovo programs, it is possible to note important common characteristics: a) the presence of a well-formed bureaucracy with relevant market experience that manages innovative and dynamic programs to support high-impact entrepreneurship and b) a structure to support high-impact entrepreneurs that, according to the entrepreneurs, helps to build a competitive advantage for the companies.

It is worth noting that the selection criteria of ventures for the FINEP forums and the criteria to provide resident status in Skolkovo are based on similar requirements for innovation in entrepreneurship, market potential, and team quality. These are market criteria, or rather, criteria similar to those used by the venture capital firm DGF INVESTIMENTOS to select potential investments.

The high-impact entrepreneurs who have benefited from the studied institutions recognize the positive role that these institutions have exerted over their ventures; in other words, they recognize that the institution created mechanisms that were fundamental for the development of their businesses. Therefore, in terms of the perspectives of the institutions and entrepreneurs (and also of venture capital stakeholders), we found that the institutional void is not absolute in the entrepreneurial activity in these countries. The gap exists, but it also coexists with the support programs for high-impact entrepreneurs that seek to partially fill this gap.

Following the journey of Daniel Heise and Yuri Deigen we can note that both became investors in new ventures and both are contributing to the development of new companies. If in one hand their entrepreurial behavior play a major role in their ability to continuously contribute to their ecosystems on the other hand governmental programs also played an important role on fostering their companies as well as their careers.

After about six years Skolkovo still growing in many ways. Not only with a growing number that can enjoy a less complex tax system but also with adequate infrastructure, innovations grants, teaching and research (Skolkovo University) among other incentives. On the other hand, FINEP INOVAR was terminated but FINEP is still supporting the entrepreneurial ecosystem with other programs like FINEP Startup. Both cases show that the discussion about formal institutional voids it is much more complex than pictured in previous research. The same state that creates difficulties to open, sustain and close business also promotes innovative companies and entrepreneurs. On other words, we see that institutions can assume a Janus Face.

This study has the limitation of being a comparative case study; that is, only two entrepreneurs affected by the programs were studied. Neither program currently has sufficient data to allow for quantitative studies.

In future studies, we suggest that the evaluation of the programs studied here be expanded. Quantitative studies based on surveys covering a large number of entrepreneurs could deepen our understanding of he Janus Face of Institutions. From a theoretical point of view, in this research, we adopted the concept of the face of Janus regarding the relationship between institutions and entrepreneurship in two emerging countries, Russia and Brazil. It is appropriate to ask whether this phenomenon also occurs in other countries, especially in less-developed countries.

\section{References}


Acs, Z. K. (2008). Foundations of high impact entrepreneurship. Foundations and Trends in Entrepreneurship, 4(6), 535-620.

Abubakar, Y., \& Mitra, J. (2017). Knowledge spillovers and high-impact growth: Comparing local and foreign firms in the UK. Journal of International Entrepreneurship, 15(2), 145-176

Ahlstrom, D. \& Bruton, G. (2010). Rapid institutional shifts and the co-evolution of entrepreneurial firms in transition economies. Entrepreneurship Theory and Practice, 34(3), 531-554.

Aidis, R. (2005). Institutional barriers to small-and medium-sized enterprises operations in transitions countries. Small Business Economics, 25(4), 305-317.

Ajjan, H., Fabian, F., Tomczyk, D., \& Hattab, G. (2015). Social Media Use to Support Entrepreneurship in the Face of Disruption. Journal of Developmental Entrepreneurship, 20(3).

Armanios, D. E., Eesley, C. E., Li, J., \& Eisenhardt, K. M. (2017). How entrepreneurs leverage institutional intermediaries in emerging economies to acquire public resources. Strategic Management Journal, 38(7), 1373-1390.

Audretcsch, D. B., Keilbach, M. C., \& Lehmann, E. E. (2006). Entrepreneurship and Economic Growth. Oxford: Oxford University Press.

Audretcsch, D. B. \& Thurik, R. (2001). What's new about new economy? Sources of growth in the managed and entrepreneurial economies. Industrial and Corporate Change, 10(1), 267-315.

Baker, T. \& Nelson, R. E. (2005). Creating something from nothing: resource construction through entrepreneurial bricolage. Administrative Science Quarterly, 50: 329-366.

Baumol, W. J. (1990). Entrepreneurship: productive, unproductive and destructive. Journal of Political Economy, 98(5), 893-921.

Birch, D. L, Haggerty, A. \& Parsons, W. (1995). Who's creating jobs? Boston: Cognetics Inc.

Bjerregaard, T. \& Lauring, J. (2012). Entrepreneurship as institutional change: strategies of bridging institutional contradictions. European Management Review, 9, 31-43.

Bjørnskov, C., \& Foss, N. J. (2016). Institutions, Entrepreneurship, and Economic Growth: What Do We Know And What Do We Still Need to Know?. Academy of Management Perspectives, 30(3), 292-315.

Bruton, G. D., Ahlstrom, D., \& Li, H. (2010). Institutional theory and entrepreneurship: where are we now and where do we need to move in the future? Entrepreneurship Theory and Practice, 34(3): 421-440.

Bruton, G. D., Ahlstrom, D., \&; Obloj, K. (2008). Entrepreneurship in emerging economies: where we are today and where should the research go in the future. Entrepreneurship Theory and Practice, 32(1), 114.

Coad, A., Cowling, M., \& Siepel, J. (2017). Growth processes of high-growth firms as a four-dimensional chicken and egg. Industrial \& Corporate Change, 26(4), 537-554

Cunneen, D. J. \& Meredith, G. G. (2007). Entrepreneurial founding activities that create gazelles. Small Enterprise Research, 15(1), 39-59.

De Jong, G., \& Van Witteloostuijn, A. (2015). Regulatory Red Tape and Private Firm Performance. Public Administration, 93(1), 34-51

DiMaggio, P. J. (1998). Interest and agency in institutional theory. In L. G. Zucker (Ed.), Institutional patterns and organizations: culture and environment: 3-21. Cambridge: Ballinger.

Eisenhardt, K.M. (1989). Building theories from case study research. Academy of Management Review, 14(4), 532-550.

Figueroa-Armijos, M., \& Johnson, T. (2016). Entrepreneurship policy and economic growth: Solution or delusion? Evidence from a state initiative. Small Business Economics, 47(4), 1033-1047

Global Entrepreneurship Research Association (GERA). The Global Entrepreneurship Monitor 2016/17. GERA.

Gohman, S. (2012). Institutions, latent entrepreneurship, and self-employment: an international comparison. Entrepreneurship Theory and Practice, 36(2), 295-321. Henrekson, M., \& Johansson, D. (2010). Gazelles as job creators. Small Business Economics, 35(2), 227-244.

Johnson, S., Kaufmann, D., \& Zoido-Lobaton, P. (1998). Regulatory Discretion and the Unofficial Economy. American Economic Review, 88(2), 387-392

Karadağ, H. (2018). A Comparative Analysis on the Relationship Between Institutional Environment and Entrepreneurship in Emerging Economies. International Journal of Eurasia Social Sciences / Uluslararasi Avrasya Sosyal Bilimler Dergisi, 9(31), 75-105.

Keilbach, M., Tamvada, J.P \& Audretsch, D. B. (2009). Sustaining entrepreneurship and economic growth. New York: Springer. 
Kickul, J., Griffiths, M., Bacq, S., \& Garud, N. (2018). Catalyzing social innovation: is entrepreneurial bricolage always good? Entrepreneurship \& Regional Development, 30(3/4), 407-420.

Kistruck, G. M., Webb, J. W., Sutter, C. J., \& Bailey, A. V. (2015). The double-edged sword of legitimacy in base-of-the-pyramid markets. Journal of Business Venturing, 30(3), 436-451

Khanna, T. \& Palepu, K. (1997). Why Focused strategies may be wrong for emerging markets. Harvard Business Review, 75(4), 41-51.

Korppoo, A. (2018). Russian associated petroleum gas flaring limits: Interplay of formal and informal institutions. Energy Policy, 116, 232-241.

Kshetri, N. (2007). Institutional changes affecting entrepreneurship in China. Journal of Developmental Entrepreneurship, 12(4), 415-432.

Kshetri; N. \& Dholakia, N. (2011). Regulative institutions supporting entrepreneurship in emerging economies: a comparison of China and India. Journal of International Entrepreneurship, 9,110-132.

Lee, S. H., Yamakawa, Y., Peng, M.W., \& Barney, J. B. (2011). How do bankruptcy laws affect entrepreneurship development around the world? Journal of Business Venturing. 26: 505-520.

Lévi-Strauss, C. (1966). The savage mind. Chicago: University of Chicago Press.

Luthans, F. \& Ibrayeva, E. S. (2006). Entrepreneurship self-efficacy in Central Asia transition economies: quantitative and qualitative analysis. Journal of International Business Studies, 37(1): 92-110.

Mair, J. \& Martí, I. (2009). Entrepreneurship in and around institutional voids: a case study from Bangladesh. Journal of Business Venturing, 29: 419-435.

Mair, J., Martí, I., \& Ventresca, M. J. (2012). Building inclusive markets in rural Bangladesh: how intermediates work institutional voids. Academy of Management Journal, 55(4): 819-850.

Manolova, T. S., Eunni, R. V., \& Gyoshev, B. S. (2008). Institutional environments for entrepreneurship: evidence from emerging economies in Eastern Europe. Entrepreneurship Theory and Practice, 32(1), 203-218.

McCarthy, D. J., \& Puffer, S. M. (2016). Institutional Voids in an Emerging Economy. Journal of Leadership \& Organizational Studies, 23(2), 208-219

McMillan, J. \& Woodruff, C. (2002). The central role of entrepreneurs in transition economies. Journal of Economic Perspectives, 16(3), 153-170.

Michael, S. C. \& Pearce. J. A. (2009). The need for innovation as a rationale for government involvement in entrepreneurship. Entrepreneurship and Regional Development, 21(3), 285-302.

Minniti, M. (2008). The role of government policy on entrepreneurial activity: productive, unproductive, or destructive? Entrepreneurship Theory and Practice, 32(5), 779-790.

Moreno, A. M. \& Casillas, J. C. (2007). High growth SMEs versus non high-growth SMEs: a discriminate analysis. Entrepreneurship and Regional Development, 19: 69-88.

North, D. C. (1990). Institutions, institutional change and economic performance. Cambridge: Cambridge University Press.

OECD. (2011). Entrepreneurship at a glance 2011. Paris: OECD Publishing.

Peci, F., Kutlovici, E., Tmava, Q., \& Shala, V. (2012). Small and medium enterprises facing institutional barriers in Kosovo. International Journal of Marketing Studies, 4(1), 95-107.

Peng, M. W. (2000). Business strategies in transition economies. Thousand Oaks: Sage.

Peng, M. W. (2006). How entrepreneurs create wealth in transition economies. In: Li, H. Growth of new technology ventures in China's emerging market, 87-111. Cheltenham, Reino Unido: Edward Elgar.

Peng, M. W., Sun, S. L., Pinkham, B., \& Chen, H. (2009). The institution-based view as a third leg for a strategy tripod. Academy of Management Perspectives, 23(4), 63-81.

Pereira, V., \& Temouri, Y. (2018). Impact of institutions on emerging European high-growth firms. Management Decision, 56(1), 175-187

Puffer, S. M., McCarthy, D.J., \& Boisot, M. (2010). Entrepreneurship in Russia and China: The impact of formal institutional voids. Entrepreneurship Theory and Practice, 34(3), 441-467.

Raynard, P. \& Forstater, M. (2002). Corporate social responsibility: implications for small and medium enterprises in developing countries. Vienna: United Nations Industrial Development Organization.

Scott, W. R. (2001). Institutions and organizations. Thousand Oaks, CA: Sage.

Shane, S. \& Foo, M. (1999) New firm survival: institutional explanations for new franchisor mortality. Management Science, 45(2), 142-159.

Smallbone, D. \& Welter, F. (2001). The role of government in SME development in transition countries. International Small Business Journal, 19(4), 63-77. 
Smit, H., Pennings, E., \& Bekkum, S. (2017). Real options and institutions. Journal of International Business Studies, 48(5), 620-644

Sobel, R. S. (2008). Testing Baumol: institutional quality and the productivity of entrepreneurship. Journal of Business Venturing, 23(6), 641-655.

Sobel, R. S., \& Clark, J. R. (2016). Interest Group Activity and Government Growth: A Causality Analysis. CATO Journal, 36(3), 507-533.

St-Jean, E. Julien, P. A., \& Audet, J. (2008). Factors associated with growth changes in 'gazelles'. Journal of Enterprising Culture, 16(2), 161-188.

Stake, R. 1995. The art of case research. Newbury Park: CA: SAGE.

Tasavori, M., Kwong, C., \& Pruthi, S. (2018). Resource bricolage and growth of product and market scope in social enterprises. Entrepreneurship \& Regional Development, 30(3/4), 336-361

Tracey, P. \& Phillips, N. (2011). Entrepreneurship in emerging markets: strategies for new ventures creation in uncertain institutional contexts. Management International Review, 51(1), 23-39.

Van Maanen, J. (1988). Tales of the field: on writing ethnography. Chicago, IL.: University of Chicago Press. Van Stel, A., Carree, M., \& Thurik, R. (2005). The effect of entrepreneurial activity on national economic growth. Small Business Economics, 24(3), 311-321.

Webb, J. W., Tihanyi, L., Ireland, R.D., \& Sirmon, D. G. (2009). You say illegal, I say legitimate: entrepreneurship in the informal economy. Academy of Management Review, 34(3): 492-510.

Yin, R.K. (2003). Case study research: design and methods. Thousand Oaks, CA: SAGE.

Zoogah, D. B., Peng, M. W., \& Woldu, H. (2015). Institutions, Resources, and Organizational

Effectiveness in Africa. Academy of Management Perspectives, 29(1), 7-31 